\title{
Factors Affecting Premature Chromosome Condensation of Cumulus Cell Nuclei Injected Into Rat Oocytes
}

\author{
Masumi HIRABAYASHI ${ }^{1)}$, Megumi KATO1,2), Ayumu TAKEUCHI ${ }^{3)}$, \\ Ayako ISHIKAWA ${ }^{1)}$ and Shinichi $\mathrm{HOCHI}^{3)}$ \\ 1) National Institute for Physiological Sciences, Okazaki, Aichi 444-8585, ${ }^{2)}$ CREST of Japan \\ Science and Technology Corporation, Kawaguchi, Saitama 332-0012, and ${ }^{3)}$ Faculty of Textile \\ Science and Technology, Shinshu University, Ueda, Nagano 386-8567, Japan
}

\begin{abstract}
To date, production of cloned rats by somatic cell nuclear transfer (NT) has not yet been successful. Inducing premature chromosome condensation (PCC) of injected cell nuclei in recipient cytoplasm is considered essential for successful mouse cloning by the Honolulu method. In the present study, some factors affecting PCC of rat cumulus cell nuclei injected into rat oocytes were examined. Wistar female rats (young: 4 to 5-week-old, mature: $\geq 10$-week-old) were superovulated by injections of eCG and hCG, and oocytes recovered 14 or $17 \mathrm{~h}$ after hCG injection were received with cumulus cell nuclei using piezo-driven micromanipulator. When the oocytes were recovered $14 \mathrm{~h}$ post-hCG injection from young rats and the nuclear injection into oocytes was completed within 45 min, PCC was observed in $44-49 \%$ of NT oocytes. In the case of oocytes from mature rats, PCC occurred in $11-19 \%$ of the NT oocytes. Oocytes recovered $17 \mathrm{~h}$ post-hCG injection did not support PCC of the injected nuclei $(0-7 \%)$ regardless of the donor age. Treatment of oocytes with a neutral cysteine protease inhibitor, $N$-acetylleucylleucylnorleucinal, slightly increased the incidence of PCC (48 vs 37\%). Comparison of rat strains for oocyte donors indicated that proportions of NT oocytes undergoing PCC in Wistar and LEW oocytes (41-46\%) were higher than those in Donryu and F344 oocytes (17-25\%). Thus, ability of rat oocytes to promote PCC of the injected nuclei is dependent on the characteristics of oocytes, such as age or strain of donor rats, and timing of oocyte recovery.

Key words: Cloning, N-acetylleucylleucylnorleucinal (ALLN), Piezo manipulator, Premature Chromosome Condensation (PCC), Rat oocytes
\end{abstract}

(J. Reprod. Dev. 49: 121-126, 2003)

$\mathbf{S}^{\mathrm{n}}$ ince the rat is widely used in the research field of neuroscience, development in methodology to produce "knock-out (KO)" rats has been long desired. The most convenient method for the production of $\mathrm{KO}$ animals is to use gene-targeted embryonic stem cells in germline chimera production, but embryonic stem cell lines have not yet been established in the rat. Animal cloning by nuclear transplantation (NT) of somatic cells, as reported in the mouse [1], rabbit [2], cat [3], goat [4],

Accepted for publication: November 18, 2002

Correspondence: S. Hochi or M. Hirabayashi sheep [5], pig [6] and cattle [7], is a revolutionary approach for producing $\mathrm{KO}$ animals. However, recent attempts to produce cloned rats using fetal fibroblast cells [8] and adult somatic cells [9-11] have not been successful, although full-term development of rat embryos reconstructed with embryonic blastomeres has been reported [12]. The keys to success in the production of cloned mice by the Honolulu method have been considered by the authors $[1,13,14]$; these include promoting the premature chromosome condensation (PCC) of injected nuclei and subsequent pronucleus (PN)- 
like vesicle formation, as well as exposing of injected nuclei directly to reprogramming factors present in the cytoplasm of recipient oocytes.

Rat oocytes have been reported to activate spontaneously during in vitro culture $[11,15,16]$. The activated oocytes extruded the second polar body within 60-90 min of culture, but development became arrested again without formation of a PN. Puromycin and chloral hydrate could trigger PN formation of spontaneously activated rat oocytes [16]. The $\mathrm{Ca}^{2+} / \mathrm{Mg}^{2+}$-free culture medium induced spontaneous PN formation and subsequent parthenogenetic first cleavage in rat oocytes [17]. Maturation promoting factor (MPF), by which PCC of donor cell nuclei is induced, may be decreased or inactivated in such spontaneously activated rat oocytes. A neutral cysteine protease inhibitor, Nacetylleucylleucylnorleucinal (ALLN), has been reported to inhibit degradation of cyclin $\mathrm{B}$ and to induce cell cycle arrest in $\mathrm{CHO}$ cells [18].

The objective of the present study was to investigate factors affecting PCC of rat cumulus cell nuclei injected into rat oocytes. The characteristics of recipient oocytes (age and strain of rats, and recovery time after hCG injection), time allowed until NT completion, and effectiveness of the ALLN were determined in order to combine them with a NT protocol.

\section{Materials and Methods}

\section{Rat oocytes}

Specific pathogen-free/virus antibody-free female rats were purchased from Charles River Japan, Inc. (Kanagawa, Japan). The rats were housed in an environmentally controlled room with a 12-h dark: 12-h light cycle at a temperature of $23 \pm 2 \mathrm{C}$ and humidity of $55 \pm 5 \%$, and given free access to a laboratory diet (MF; Oriental Yeast, Co., Tokyo, Japan) and filtered water. Superovulation of the rats was induced by intraperitoneal injections of equine chorionic gonadotrophin (eCG; Nippon Zenyaku, Co., Fukushima, Japan) and human chorionic gonadotrophin (hCG; Sankyo, Co., Tokyo, Japan) 48 hours apart, as described previously [19]. The rats were sacrificed by cervical dissociation. Cumulus-oocyte complexes (COCs) were recovered from the oviductal ampullae with modified KRB medium [20] containing $0.1 \%$ hyaluronidase (Sigma-Aldrich Corp., St. Louis,
MO) at $37 \mathrm{C}$. The denuded oocytes were washed three times with fresh modified KRB medium and kept at $37 \mathrm{C}$ until use.

\section{Nuclear transplantation}

Cumulus cells dispersed from COCs by the hyaluronidase treatment were placed in modified KRB medium containing $22 \mathrm{mM}$ Hepes and $5 \mathrm{mM}$ $\mathrm{NaHCO}_{3}$ (Hepes-KRB medium). An aliquot (2 $\left.\mu \mathrm{l}\right)$ of the cumulus cell suspension was transferred to $10 \mu \mathrm{l}$ of Hepes-KRB medium supplemented with $12 \%$ polyvinyl pyrrolidone ( $\mathrm{w} / \mathrm{v}$; PVP, $360 \mathrm{kDa}$; ICN Pharmaceuticals, Inc., Costa Mesa, CA). Nuclei of cumulus cells were isolated just before injection with shear stress using a blunt-end pipette $7-10 \mu \mathrm{m}$ in diameter and a piezo-micromanipulator (Prime Tech, Ibaraki, Japan). Then, single nuclei were aspirated into the pipette and injected into a non-enucleated oocyte. One hour after the injection, the oocytes were stained with $5 \mu \mathrm{g} / \mathrm{ml}$ Hoechst 33342 (Sigma-Aldrich) and examined for incidence of PCC under UV light at 330-380 nm (Fig. 1). The injected somatic cell nucleus was distinguished from the oocyte nucleus by the position of the opening in the zona pellucida at the nuclear microinjection site.

\section{Experiment 1}

Effect of age of donor rats, timing of oocyte recovery, and time allowed until NT completion on PCC of injected nuclei were examined in a factorial

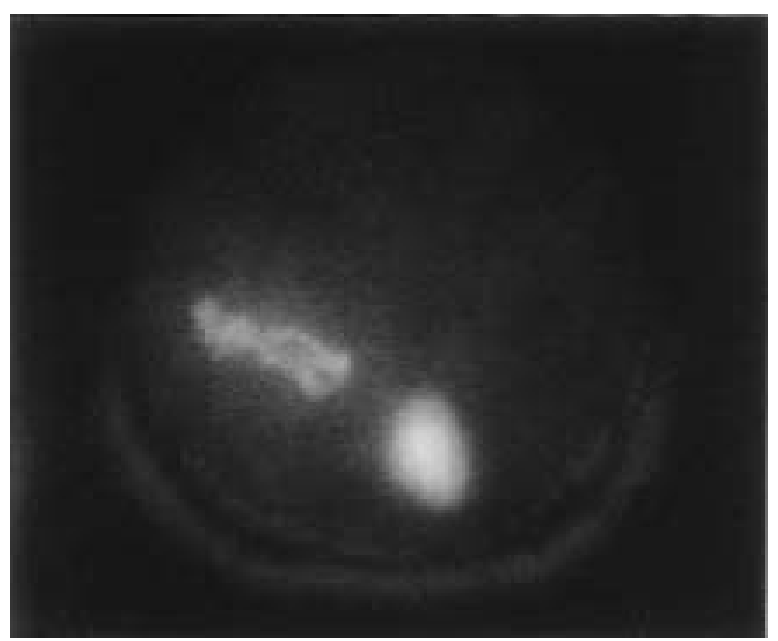

Fig. 1. Premature chromosome condensation of rat cumulus cell nucleus injected into metaphase-II stage rat oocytes (Left) 
design of $2 \times 2 \times 3$. The oocyte donor rats were either 4 to 5 -week-old (young: $\mathrm{n}=10$ ) or $>10$-weekold (mature: $n=10$ ) of Wistar strain. The young rats were treated with eCG/hCG (300 IU/kg each) regardless of their estrous stages while the mature rats had to be treated with eCG $(150 \mathrm{IU} / \mathrm{kg})$ at the diestrous-stage and with hCG $(75 \mathrm{IU} / \mathrm{kg})$ at the proestrous-stage [19]. The rats were sacrificed either 14 or $17 \mathrm{~h}$ after hCG injection, then the oocytes were recovered. Nuclear injection was completed within 16-30 min, 31-45 min, or 46-60 min (time of sacrifice of the rat was defined as 0 $\mathrm{min}$ ), and oocytes derived from a single donor rat were allocated to these 3 groups.

\section{Experiment 2}

The effect of ALLN on PCC of injected nuclei was examined. The oocytes were recovered $14 \mathrm{~h}$ after hCG injection from young Wistar rats, and nuclear injection was completed within 16-60 $\mathrm{min}$. The ALLN (Sigma-Aldrich) at a concentration of $20 \mu \mathrm{g} /$ $\mathrm{ml}$ was added to all the media to which the oocytes were exposed. After nuclear injection the oocytes were washed three times with ALLN-free HepesKRB medium and kept for $1 \mathrm{~h}$ until the PCC assay.

\section{Experiment 3}

The effect of rat strains on PCC of injected nuclei was examined. The strains to be compared were Wistar (closed colony), Donryu (closed colony), LEW (inbred), and F344 (inbred). The oocytes were recovered $14 \mathrm{~h}$ after hCG injection from 5-week-old female rats ( $\mathrm{n}=5$ each), and nuclear injection was completed within 16-60 min.

\section{Statistics}

The data for PCC incidence were analyzed by Fisher's exact probability test using the StatView program (Abacus Concepts, Inc., Berkeley, CA). Oocyte recovery rates among rat strains were compared by Student's $t$-test. A value of $P<0.05$ was chosen as an indication of statistical significance.

\section{Results}

\section{Experiment 1}

Oocytes derived from young, 4 to 5-week-old rats were more sensitive to mechanical piercing of plasma membrane by piezo-driven micropipettes than oocytes derived from mature $\geq 10$-week-old rats (survival $65.7 \%, 249 / 379$ vs. $83.0 \%, 278 / 335$; $P<0.05)$. Age of oocyte donors (4-5 vs. $\geq 10$-weekold) and timing of oocyte recovery (14 vs. $17 \mathrm{~h}$ post hCG injection) were among the possible factors influencing PCC of injected cumulus cell nuclei (Table 1). Higher proportions of oocytes derived from the young rats $(43.9-48.5 \%)$ carried the potential to support PCC than those from the mature rats $(11.4-16.3 \%)$ when nuclear injection was completed within $45 \mathrm{~min}$. The incidence of PCC in oocytes $14 \mathrm{~h}$ post-hCG from young rats $(23.3 \%)$ decreased significantly if it took $60 \mathrm{~min}$ until the nuclear injection was completed. Oocytes recovered $17 \mathrm{~h}$ post hCG injection did not support PCC of injected nuclei $(0-6.8 \%)$ regardless of the age of donor rats.

\section{Experiment 2}

Addition of ALLN to all the media during oocyte recovery to NT slightly increased the incidence of PCC of injected nuclei (Table 2), but the increase (48.1 vs. $36.8 \%)$ was not statistically significant $(P=$ 0.21). Treatment of oocytes with the ALLN did not affect the survival rate after nuclear injection.

Table 1. Effect of characteristics of rat oocytes, and time from oocyte recovery to NT completion on incidence of premature chromosome condensation of injected donor nuclei

\begin{tabular}{|c|c|c|c|c|}
\hline \multicolumn{2}{|c|}{ Oocyte characteristic } & \multirow{2}{*}{\multicolumn{3}{|c|}{$\begin{array}{c}\text { PCC-positive oocytes/examined oocytes (\%) } \\
\text { Elapsed time until NT completion }\end{array}$}} \\
\hline \multirow{2}{*}{$\begin{array}{c}\text { Age of } \\
\text { oocyte donors }\end{array}$} & \multirow{2}{*}{$\begin{array}{c}\text { Timing of } \\
\text { oocyte recovery }\end{array}$} & & & \\
\hline & & $16-30 \mathrm{~min}$ & $31-45 \mathrm{~min}$ & $46-60 \mathrm{~min}$ \\
\hline \multirow{2}{*}{4 to 5 -week-old } & $14 \mathrm{~h}$ post $\mathrm{hCG}$ & $25 / 57(43.9)^{a}$ & $16 / 33(48.5)^{\mathrm{a}}$ & $10 / 43(23.3)^{b}$ \\
\hline & $17 \mathrm{~h}$ post $\mathrm{hCG}$ & $3 / 44(6.8)^{b c d}$ & $0 / 38(0)^{\mathrm{cd}}$ & $0 / 34(0)^{\mathrm{cd}}$ \\
\hline \multirow[t]{2}{*}{$\geq 10$-week-old } & $14 \mathrm{~h}$ post $\mathrm{hCG}$ & $8 / 49(16.3)^{b}$ & $5 / 44(11.4)^{\mathrm{bc}}$ & $9 / 48(18.8)^{\mathrm{b}}$ \\
\hline & $17 \mathrm{~h}$ post $\mathrm{hCG}$ & $0 / 52(0)^{\mathrm{d}}$ & $0 / 49(0)^{\mathrm{d}}$ & $0 / 36(0)^{\mathrm{cd}}$ \\
\hline
\end{tabular}

a-d Significantly different between different superscripts. 
Table 2. Effect of $\mathrm{N}$-acetylleucylleucylnorleucinal on incidence of premature chromosome condensation of injected donor nuclei

\begin{tabular}{cccc}
\hline & \multicolumn{3}{c}{ No.(\%) of oocytes } \\
\cline { 2 - 4 } ALLN & Injected & Survived & PCC-induced \\
\hline- & 94 & $68(72.3)$ & $25(36.8)$ \\
+ & 79 & $54(68.4)$ & $26(48.1)$ \\
\hline
\end{tabular}

\section{Experiment 3}

The mean number of oocytes recovered per donor rat was the highest in the Wistar strain, followed by Donryu, LEW, and F344 (Table 3). Oocytes from inbred rat strains (LEW and F344) tended to be more sensitive to microinjection than those from closed colony strains (Wistar and Donryu). The proportions of Wistar and LEW oocytes supporting PCC of injected nuclei (45.5 and $41.2 \%$, respectively) were higher than that of Donryu oocytes $(17.1 \%)$ and tended to be higher than that of F344 oocytes (25.0\%).

\section{Discussion}

The first successful technique to produce cloned animals was NT by electrofusion of G0/G1-phase donor cells with enucleated oocytes and simultaneous activation of the reconstructed zygotes [2-5, 7, 14]. In mice, NT by microinjection of donor cell nuclei into enucleated oocytes and subsequent activation treatment 1-6 hours post injection (Honolulu method) $[1,6,13,14]$ is the most popular approach for cloning. Also, NT by HVJ-mediated fusion of NT-derived pronuclei with enucleated pronuclear zygotes (serial NT method) [21] has been reported. As for rats, earlier experiments for cloning with somatic cells [9-11] have been attempted by the Honolulu method.
Promoting PCC of injected nuclei and subsequent PN formation as well as exposing of injected nuclei directly to reprogramming factors present in the cytoplasm of recipient oocytes are necessary steps for the successful production of cloned mice by the Honolulu method $[1,13,14]$. Since the donor nuclei were injected into non-enucleated intact oocytes in the present study, the presence of metaphase-plate of the oocyte may affect the incidence of PCC in the injected donor nuclei. Ookata et al. [22] reported that, in starfish oocytes, MPF existed near the chromatin structure at the M-phase of the cell cycle although the MPF spread over the cytoplasm at the G2-phase. However, in mouse cloning [1, 13, 14], at least, removal of metaphase-plate from oocytes seems not to affect the MPF activity of oocytes, and the PCC incidence and PN formation of injected nuclei.

In the present study (Experiment 1), approximately half of the oocytes derived from young Wistar strain rats carried the potential to support PCC of injected cumulus cell nuclei, when the oocytes were recovered $14 \mathrm{~h}$ after hCG injection and nuclear injection was completed within $45 \mathrm{~min}$. In mice, PCC was observed in more than $90 \%$ of oocytes injected with cumulus cell nuclei (data not shown). The very time-limited potential of rat oocytes may be related to the fact that rat oocytes activate spontaneously in vitro $[11,15,16]$. Our previous data indicated that $95 \%$ of denuded rat oocytes were still arrested in metaphase-II stage 10 min after dissociation, but the proportion of oocytes progressing to anaphase-II or telophase-II increased in a time-dependent manner: $33 \%$ after 40 min, $69 \%$ after $70 \mathrm{~min}$, and $82 \%$ after $130 \mathrm{~min}$ [11]. In addition, the higher susceptibility to activation stimulus in aged oocytes than in freshly ovulated oocytes has been reported in the mouse [23] and rat [17]. Spontaneous activation of rat oocytes

Table 3. Effects of rat strains on premature chromosome condensation of injected cumulus cell nucleus in rat oocytes

\begin{tabular}{lcccc}
\hline & Mean No. of oocytes & \multicolumn{3}{c}{ No.(\%) of oocytes } \\
\cline { 3 - 5 } Strains & recovered per donor rat & Injected & Survived & PCC-induced \\
\hline Wistar & $28.0^{\mathrm{a}}$ & 66 & $44(66.7)$ & $20(45.5)^{\mathrm{a}}$ \\
Donryu & $23.4^{\mathrm{ab}}$ & 63 & $41(65.1)$ & $7(17.1)^{\mathrm{b}}$ \\
LEW & $18.6^{\mathrm{ab}}$ & 63 & $34(54.0)$ & $14(41.2)^{\mathrm{a}}$ \\
F344 & $9.0^{\mathrm{b}}$ & 39 & $20(51.3)$ & $5(25.0)^{\mathrm{ab}}$ \\
\hline
\end{tabular}

\footnotetext{
a-b Significantly different between different superscripts within columns.
} 
recovered $17 \mathrm{~h}$ after hCG injection may occur more easily than that of oocytes recovered $14 \mathrm{~h}$ after hCG injection, and rat oocytes may resume their second meiosis immediately after ovulation even in vivo. The use of young rats, in which an eCG/hCG regimen for superovulation can be applied regardless of their estrous stage, would have a practical advantage in the preparation of recipient oocytes for NT experiments, as previously reported for the production of transgenic rats [19].

Supplementation of a neutral cysteine protease inhibitor, ALLN, to all the media for oocyte recovery to microinjection slightly, but not significantly, increased PCC incidence of injected cumulus cell nuclei (Experiment 2). The action of ALLN on cell-cycle arrest is associated with the inhibition of cyclin B degradation [18]. If the spontaneously activated rat oocytes still contained a MPF level high enough to induce PCC of injected nuclei, further inactivation of the MPF may be prevented by the treatment with ALLN. An inhibitor of anaphase-promoting complex (APC)dependent ubiquitination, such as okadaic acid (inhibitor of protein phosphatase 2A), prevents the initiation of anaphase-II in Xenopus eggs [24]. An inhibitor of protein phosphorylation, such as 6dimethylaminopurine (6-DMAP), blocks maturation of starfish oocytes [25]. In mice, oocytes treated with okadaic acid or 6-DMAP arrested their second meiotic division at the metaphase [26, 27], while 6-DMAP has the potential to activate a cascade of cellular changes necessary for meiotic resumption in some oocytes [27]. Other than ALLN, okadaic acid and 6-DMAP may be chemical candidates capable of inhibiting the progress of MPF inactivation in the rat oocytes.

There are more than 100 rat strains with various genetic backgrounds. Among them, Wistar and Sprague-Dawley (SD) strain rats are the most frequently used in various types of experiments, but no information has been available on the strain suitability of oocyte donors in NT protocols. Earlier reports of attempted rat cloning [9-11] have used SD strain rats as oocyte donors, because of the higher in vitro developmental potential of SD versus WF, LEW, F344, PVG zygotes [10], and the higher response of SD versus Wistar oocytes to activation treatment with strontium chloride [11]. In a parallel study, we determined the rat strain for somatic cell donors, F1 hybrid of SD $\times$ Dark-Agouti, and it is one reason why the SD strain was not used in the comparison of PCC in the present study (Experiment 3). In general, oocytes from inbred rat strains seem to be more sensitive to mechanical stimuli than those from outbred strains [28]. There was a tendency for rat oocytes from inbred strains (LEW and F344) to be more sensitive to nuclear microinjection than those from closed colony strains (Wistar and Donryu) in the present study. Further research is required to explain the potential difference of oocytes for supporting PCC of injected nuclei between rat strains.

In conclusion, the potential of rat oocytes to support PCC of injected nuclei is dependent on the characteristics of the oocytes, such as age or strain of donor rats, as well as the timing of oocyte recovery. Based on the present results, oocytes recovered $14 \mathrm{~h}$ after hCG injection from young 4 to 5 -week-old rats of Wistar or LEW strain need to be used for nuclear injection as soon as possible. Treatment of oocytes with ALLN to maintain the meiotic arrest may be beneficial.

\section{Acknowledgements}

The authors thank Dr. Kunihiko Naito (The University of Tokyo) for his helpful suggestions on the use of $\mathrm{N}$-acetylleucylleucylnorleucinal. This work was supported by a Grant-in-Aid from the Ministry of Education, Culture, Sports, Science and Technology of Japan (No. 12794020).

\section{References}

1. Wakayama T, Perry ACF, Zuccotti M, Johnson KR, Yanagimachi R. Full-term development of mice from enucleated oocytes injected with cumulus cell nuclei. Nature 1998; 394: 369-374.

2. Chesne P, Adenot PG, Viglietta C, Baratte $M$, Boulanger L, Renard JP. Cloned rabbits produced by nuclear transfer from adult somatic cells. Nat Biotechnol 2002; 20: 366-369.

3. Shin T, Kraemer D, Pryor J, Liu L, Rugila J, Howe L, Buck S, Murphy K, Lyons L, Westhusin M. A cat cloned by nuclear transplantation. Nature 2002; 415: 859. 
4. Baguisi A, Behboodi E, Melican DT, Pollock JS, Destrempes MM, Cammuso C, Williams JL, Nims SD, Porter CA, Midura P, Palacios MJ, Ayres SL, Denniston RS, Hayes ML, Ziomek CA, Meade HM, Godke R, Gavin WG, Overstrom EW, Echelard Y. Production of goats by somatic cell nuclear transfer. Nat Biotechnol 1999; 17: 456-461.

5. Wilmut I, Schnieke, AE, McWhir J, Kind AJ, Campbell KHS. Viable offspring derived from fetal and adult mammalian cells. Nature 1997; 385: 810813.

6. Onishi A, Iwamoto M, Akita T, Mikawa S, Takeda K, Awata T, Hanada H, Perry AC. Pig cloning by microinjection of fetal fibroblast nuclei. Science 2000; 289: 1188-1190.

7. Kato Y, Tani T, Sotomaru Y, Kurokawa K, Kato J, Doguchi H, Yasue H, Tsunoda Y. Eight calves cloned from somatic cells of a single adult. Science 1998; 282: 2095-2098.

8. Fitchev $\mathbf{P}$, Taborn $\mathbf{G}$, Garton $\mathbf{R}$, Iannaccone $\mathbf{P}$. Nuclear transfer in the rat: potential access to the germline. Transplant Proc 1999; 31: 1525-1530.

9. Hayes E, Galea S, Verkuylen A, Pera M, Morrison J, Lacham-Kaplan O, Trounson A. Nuclear transfer of adult and genetically modified fetal cells of the rat. Physiol Genomics 2001; 5: 193-203.

10. Iannaccone $\mathbf{P}$, Taborn G, Garton R. Preimplantation and postimplantation development of rat embryos cloned with cumulus cells and fibroblasts. Zygote 2001; 9: 135-143.

11. Kato M, Hirabayashi M, Aoto T, Ito K, Ueda M, Hochi S. Strontium-induced activation regimen of rat oocytes for somatic cell nuclear transplantation. $J$ Reprod Dev 2001; 47: 407-413.

12. Kono T, Shioda $\mathbf{Y}$, Tsunoda $\mathbf{Y}$. Nuclear transplantation of rat embryos. J Exp Zool 1988; 248: 303-305.

13. Wakayama T, Rodriguez I, Perry AC, Yanagimachi R, Mombaerts P. Mice cloned from embryonic stem cells. Proc Natl Acad Sci USA 1999; 96: 14984-14989.

14. Ogura A, Inoue $\mathbf{K}$, Takano $\mathbf{K}$, Wakayama $\mathbf{T}$, Yanagimachi R. Birth of mice after nuclear transfer by electrofusion using tail tip cells. Mol Reprod Dev 2000; 57: 55-59.

15. Keefer CL, Schuetz, AW. Spontaneous activation of ovulated rat oocytes during in vitro culture. J Exp Zool 1982; 224: 371-377.

16. Zernicka-Goetz M. Spontaneous and induced activation of rat oocytes. Mol Reprod Dev 1991; 28: 169-176.
17. Takeuchi A, Kato M, Ito K, Kimura K, Hanada A, Hirabayashi M, Hochi S. Effect of $\mathrm{Ca}^{2+} / \mathrm{Mg}^{2+}$-free culture condition on spontaneous first cleavage of rat oocytes. J Reprod Dev 2002; 48: 243-248.

18. Sherwood SW, Kung AL, Roitelman J, Simoni RD, Schimke RT. In vivo inhibition of Cyclin B degradation and induction of cell-cycle arrest in mammalian cells by the neutral cysteine protease inhibitor N-acetylleucylleucylnorleucinal. Proc Natl Acad Sci USA 1993; 90: 3353-3357.

19. Hirabayashi M, Ito K, Sekimoto A, Hochi S, Ueda M. Production of transgenic rats using young Sprague-Dawley females treated with PMSG and hCG. Exp Anim 2001; 50: 365-369.

20. Toyoda Y, Chang MC. Fertilization of rat eggs in vitro by epididymal spermatozoa and the development of eggs following transfer. J Reprod Fertil 1974; 36: 9-22.

21. Ono Y, Shimozawa N, Ito M, Kono T. Cloned mice from fetal fibroblast cells arrested at metaphase by a serial nuclear transfer. Biol Reprod 2001; 64: 44-50.

22. Ookata K, Hisanaga S, Okano T, Tachibana K, Kishimoto T. Relocation and distinct subcellular localization of p34cdc2-cyclin B complex at meiosis reinitiation in starfish oocytes. EMBO J 1992; 11: 1763-1772.

23. Surani AM, Kaufman MH. Influence of extracellular $\mathrm{Ca}^{2+}$ and $\mathrm{Mg}^{2+}$ ions on the second meiotic division of mouse oocytes: Relevance to obtaining haploid and diploid parthenogenetic embryos. Dev Biol 1977; 59: 86-90.

24. Vorlaufer E, Peters JM. Regulation of the cyclin B degradation system by an inhibitor of mitotic proteolysis. Mol Biol Cell 1998; 9: 1817-1831.

25. Neant I, Guerrier P. 6-dimethylaminopurine blocks starfish oocyte maturation by inhibiting a relevant protein kinase activity. Exp Cell Res 1988; 176: 68-79.

26. de Pennart H, Verlhac $\mathbf{M H}$, Cibert C, Santa Maria A, Maro B. Okadaic acid induces spindle lengthening and disrupts the interaction of microtubules with the kinetochores in metaphase IIarrested mouse oocytes. Dev Biol 1993; 157: 170-181.

27. Moses RM, Masui Y. Enhancement of mouse egg activation by the kinase inhibitor, 6dimethylaminopurine (6-DMAP). J Exp Zool 1994; 270: 211-218.

28. Charreau B, Tesson L, Soulillou JP, Pourcel C, Anegon G. Transgenesis in rats: technical aspects and models. Transgenic Res 1996; 5: 223-234. 